SYLWIA KONARSKA-ZIMNICKA - KIELCE

\title{
KONFERENCJA NAUKOWA „RUBRYCELE I SCHEMATYZMY KOŚCIOLA W POLSCE”. KIELCE 23-25 MAJA 2014
}

W dniach 23-25 maja 2014 r. w Kielcach odbyła się konferencja naukowa archiwistów kościelnych, zatytułowana Rubrycele $i$ schematyzmy Kościoła w Polsce, dedykowana śp. ks. prof. Stanisławowi Librowskiemu. Konferencję zorganizowało obchodzące jubileusz 75-lecia istnienia Archiwum Diecezjalne w Kielcach oraz związane z nim Towarzystwo Przyjaciół Archiwum Diecezjalnego w Kielcach im. bł. Wincentego Kadłubka. Współorganizatorami konferencji byli: Instytut Historii Uniwersytetu Jana Kochanowskiego w Kielcach, Katedra Historii Kościoła w Czasach Nowożytnych, Metodologii i Nauk Pomocniczych Katolickiego Uniwersytetu Lubelskiego Jana Pawła II, Katedra Historii Kościoła w XIX i XX wieku Katolickiego Uniwersytetu Lubelskiego Jana Pawła II, Ośrodek Archiwów, Bibliotek i Muzeów Kościelnych Katolickiego Uniwersytetu Lubelskiego Jana Pawła II oraz Katedra Archiwistyki i Nauk Pomocniczych Historii Uniwersytetu Papieskiego Jana Pawła II w Krakowie. Partnerami merytorycznymi byli: Wyższe Seminarium Duchowne w Kielcach, Koło Historyczne Wyższego Seminarium Duchownego w Kielcach, Archiwum Państwowe w Kielcach, Muzeum Historii Kielc, Świętokrzyski Instytut Teologiczny w Kielcach, Polskie Towarzystwo Historyczne Oddział w Skarżysku-Kamiennej oraz Duszpasterstwo Akademickie Wesoła 54. Patronat medialny objęli: Wydawnictwo Jedność, Radio eM oraz Niedziela Kielecka. Konferencja została objęta honorowym patronatem Biskupa Kieleckiego Kazimierza Ryczana, Prezydenta Miasta Kielce Wojciecha Lubawskiego oraz Stift Kloster Neuburg.

Obrady naukowe otworzyli uroczyście JM Rektor Wyższego Seminarium Duchownego w Kielcach i jednocześnie Delegat Biskupi ks. dr Paweł Tambor, Przewodniczący Rady Miasta Kielce Tomasz Bogucki, Dyrektor Archiwum Państwowego w Kielcach Wiesława Rutkowska oraz Dyrektor Instytutu Historii Uniwersytetu Jana Kochanowskiego w Kielcach dr hab. Beata Wojciechowska prof. UJK.

Konferencję rozpoczął blok tematyczny zatytułowany Rubrycele $i$ schematy- 
zmy diecezjalne w czasach staropolskich. Moderatorami Sesji I byli ks. bp prof. dr hab. Jan Kopiec oraz ks. prof. dr hab. Józef Marecki. Pierwszy referat zatytułowany Rubrycele i schematyzmy diecezji wrocławskiej wygłosił ks. bp prof. dr hab. Jan Kopiec (Uniwersytet Opolski), który już we wstępie swojego wystąpienia podkreślił, iż jego celem jest ,analiza długiego historycznego procesu konstytuowania się cyklicznego wydawnictwa, ilustrującego strukturę organizacyjną i obsadę personalną centralnych urzędów diecezjalnych oraz poszczególnych jej parafii $^{1}$. Referent stwierdził, że pierwocin schematyzmów można się dopatrzyć już $\mathrm{w}$ średniowiecznych sprawozdaniach z poboru świętopietrza (dla diecezji wrocławskiej pochodzą one z lat 1334-1342). Z okresu nowożytnego natomiast zachował się wykaz kościołów-parafii całej diecezji z 1667 r.; ponadto datowane na początek XVIII w. dwa rękopiśmienne opracowania z lat 1724 oraz 1738. Natomiast pierwszym drukowanym schematyzmem diecezji wrocławskiej był Catalogus Almae Dioecesis Silesiae z roku 1748, który zapoczątkował, w ramach starej, niemieckiej diecezji wrocławskiej, tradycję w miarę regularnego, corocznego ukazywania się schematyzmów, których komplet przechowywany jest w Bibliotece Kapitulnej we Wrocławiu.

Kolejny z referentów, ks. prof. dr hab. Anzelm Weiss (Katolicki Uniwersytet Lubelski Jana Pawła II) podjął niezwykle ważny temat Marginaliów w elenchusach. Elenchusy bez wątpienia są niezwykle cennymi, acz nie do końca docenianymi źródłami do poznania przeszłości nie tylko Kościoła, ale również ludzi ten Kościół tworzących. Jednakże, co podkreślił referent, równie ważne są marginalia na tychże drukach znajdowane. Zapiski te mogą świadczyć nie tylko o proweniencji poszczególnych egzemplarzy, ale przede wszystkim o ich poczytności. Fakt, że w wielu wydaniach odnajdujemy celowo dołączone do całości wolne karty przeznaczone właśnie na odręczne notatki świadczy bez wątpienia o potrzebie dokonywania takowych. Bywa także, że to właśnie treść marginaliów może stanowić samodzielne źródło dla badaczy różnych dyscyplin, odkrywając przed nimi rozmaite aspekty życia ludzi współczesnych ukazującym się wówczas elenchusom. Ks. prof. A.Weiss wygłosił niezwykle ważną i celną refleksję, podług której elenchusy dają świadectwo samostanowienia diecezji, dla których wydanie własnego, diecezjalnego schematyzmu miało znaczenie nie tylko informacyjne, ale przede wszystkim podkreślało ich tożsamość i wyodbrębniało je spośród innych diecezji.

Kwestie zasygnalizowane przez ks. prof. A. Weissa zostały szeroko omówione przez ks. prof. dra hab. Józefa Mareckiego (Uniwersytet Papieski Jana Pawła II w Krakowie) w wystąpieniu zatytułowanym Schematyzmy jako źródło historyczne. Autor referatu stanowczo podkreślił wagę tychże źródeł dla pełniejszego poznania historii poszczególnych diecezji, ukazując na konkretnych przykładach konieczność prowadzenia systematycznych, pogłębionych badań nad tymi jakże ciekawymi, a jednocześnie niezwykle wymagającymi źródłami.

Ostatnim referatem w części pierwszej było wystąpienie ks. dra Łukasza Kru-

${ }^{1}$ Bp J. Kopiec, Rubrycele i schematyzmy diecezji wrocławskiej, www.archiwum.diecezja.kielce.pl/index.php/konferencja-23-25052014/abstrakty-23-2505201 [dostęp: 26. 05. 2014 r.]. 
ckiego (Archiwum Archidiecezjalne w Gnieźnie) pt. Katalog schematyzmów archidiecezji gnieźnieńskiej znajdujacych się w księgozbiorze podręcznym Archiwum Archidiecezjalnego w Gnieźnie (1763-2013/2014). Autor podjął w nim udaną próbę charakterystyki gnieźnieńskich schematyzmów wydawanych w latach 1763-2014. Zasadniczym celem wystąpienia było prześledzenie ewolucji owych druków, mających swe korzenie w dorocznych kalendarzach liturgicznych, które w XVIII w. zostały wzbogacone o dodatek obejmujący spisy kanoników Kapituły Metropolitalnej w Gnieźnie i zmarłych księży, a od 1806 r. powiększone o część informacyjną, dotyczącą poszczególnych parafii i duchownych pracujących w archidiecezji świętowojciechowej. Ks. dr Ł. Krucki zwrócił uwagę również na fakt, iż pomimo unii personalnej łączącej Gniezno i Poznań (1821-1946) dopiero od 1929 r. zaczął ukazywać się Rocznik archidiecezji gnieźnieńskiej i poznańskiej, a wiec wydawnictwo, które, podług referenta „do dziś posiada znamiona „współczesności². Szczegółowa charakterystyka schematyzmów aż po 2014 r. pozwoliła referentowi zrealizować założenie, jakie przyświecało wystąpieniu - ukazać ewolucję i wskazać zmiany, jakie na przestrzeni wieków dokonywały się w schematyzmach archidiecezji gnieźnieńskiej.

Po krótkiej przerwie wznowiono obrady i jako pierwsza wystąpiła mgr Alina Baran (Uniwersytet Jagielloński) z referatem poświęconym Szesnastowiecznym rubrycelom diecezji krakowskiej w zbiorach Biblioteki Jagiellońskiej. Referentka podjęła próbę charakterystyki nielicznych, zachowanych fragmentarycznie rubrycel z lat 1507-1560, które drukowane były przez słynnych krakowskich drukarzy Jana Hallera i Floriana Unglera. Podkreśliła przy tym, iż większość rubrycel została odzyskana jako makulatura wydobyta $\mathrm{z}$ opraw innych starodruków przez Kazimierza Piekarskiego.

Rubrycele także diecezji krakowskiej, ale z późniejszego okresu, stały się przedmiotem rozważań kolejnego referenta - ks. prof. dra hab. Jana Szczepaniaka (Uniwersytet Papieski Jana Pawła II w Krakowie), który wystąpienie zatytułował Katalog rubrycel i schematyzmów diecezji krakowskiej zachowanych w Archiwum Kurii Metropolitalnej w Krakowie (1751-1800). W księgozbiorze podręcznym Archiwum Kurii Metropolitalnej przechowywany jest znaczny zbiór kalendarzy liturgicznych drukowanych dla duchowieństwa diecezji krakowskiej. Z pierwszej połowy XVIII w. zachowały się tylko trzy egzemplarze z lat 1735, 1738 i 1745. Od 1750 r., co podkreślił referent, zbiór jest prawie kompletny. Brakuje tylko 9 roczników z 2. połowy XVIII w. $(1753,1754,1755,1756,1775,1779,1781$, $1784,1789)$ oraz 8 roczników z XIX w. (1802-1804, 1806, 1808-1810, 1839). Ks. prof. J. Szczepaniak poddał analizie wymienione starodruki i prześledził zmiany pojawiające się w ich treści; zwrócił również uwagę na fakt, iż w zachowanych egzemplarzach rubrycel znajdują się nierzadko bardzo ciekawe uwagi właścicieli, luźne, nie związane z treścią rubrycel zapiski, ponadto korekty zauważonych nieścisłości w rubrykach oraz różnego rodzaju notatki ad rem i uzupełnienia.

Ks. dr hab. Jarosław Marczewski (Katolicki Uniwersytet Lubelski Jana Pawła

\footnotetext{
${ }^{2}$ Ks. Ł. Krucki, Katalog schematyzmów archidiecezji gnieźnieńskiej znajdujacych się w księgozbiorze podręcznym Archiwum Archidiecezjalnego w Gnieźnie, www.archiwum.diecezja.kielce.pl/ index.php/konferencja-23-25052014/abstrakty-23-2505201 [dostęp: 26. 05. 2014 r.].
} 
II) wygłosił referat na temat Rubrycele i schematyzmy diecezji chetmsko-lubelskiej? Questio iuris et questio facti. Swoje rozważania referent zaczął od wyjaśnienia kwestii związanych z nazwą diecezji chełmsko-lubelskiej, podkreślając, iż formalnie Stolica Apostolska, pomimo zatwierdzenia zmian terytorialnych, nie zmieniła nazwy diecezji, pozostając przy dotychczasowym określeniu diecezji mianem „,chełmska”. Z tej też przyczyny sporną kwestią okazuje się być status wydawanych wówczas rubrycel, mimo wszystko określanych mianem chełmskolubelskie, których w latach 1791-1807 wydano łącznie 17. Co istotne, żadna z zachowanych rubrycel chełmsko-lubelskich nie została zaopatrzona w informację o miejscu i roku wydania, ani też o drukarni, w której została wydrukowana. Ks. J. Marczewski, omówiwszy tytułowe rubrycele i schematyzmy, zwrócił uwagę na fakt, iż rubrycele chełmsko-lubelskie w większości wypadków nie zostały odnotowane w Bibliografii polskiej Estreichera, pomimo tego, że wszystkie można odnaleźć w lubelskich instytucjach bibliotecznych i archiwalnych.

Ostatnim referat pierwszego dnia konferencji wygłosił ks. dr Piotr Górecki (Archiwum Diecezjalne w Gliwicach) pt. Opolskie i gliwickie roczniki diecezjalne. Swoje rozważania referent rozpoczął od przedstawienia okoliczności powołania do życia tytułowych diecezji. Dzieje samodzielnej diecezji opolskiej datują się dopiero od 1972 r. W 1992 roku decyzją papieża Jana Pawła II nastąpiła reorganizacja diecezji w Polsce, na skutek której 25 III 1992 r. na mocy bulli Totus Tuus Poloniae Populus została utworzona nowa diecezja gliwicka (przypadło jej 90 parafii z diecezji opolskiej; jej północną część stanowi sześć dekanatów należących przedtem do diecezji katowickiej). Nowa diecezja gliwicka wraz z opolską włączone zostały do świeżo powołanej metropolii górnośląskiej z siedzibą w Katowicach. Ważnym aspektem działalności obydwu diecezji było wydawanie rubrycel i schematyzmów. Dla diecezji opolskiej (do 1972 r. Administracji Apostolskiej), w latach 1947-2010, ukazało się 19 roczników diecezjalnych. I to właśnie one stały się przedmiotem rozważań referenta, który krok po kroku ukazywał zmiany zachodzące w treści i formie publikowanych druków.

Wysłuchawszy ostatniego referatu przewodniczący Sesji I ks. bp. prof. dr hab. Jan Kopiec oraz ks. prof. dr hab. Józef Marecki podziękowali wszystkim referentom i otworzyli dyskusję, która pozwoliła uszczegółowić budzące szczególne zainteresowanie słuchaczy kwestie poruszane w czasie wystąpień. Głos zabrało wielu licznie przybyłych na konferencję gości, jak również prelegenci, którzy po raz kolejny podkreślali znaczenie rubrycel i elenchusów jako źródła historycznego.

Kolejny dzień konferencji, 24 maja 2014 r., rozpoczęła Sesja II, zatytułowana Rubrycele i schematyzmy diecezjalne w czasach współczesnych (XIX-XXI w.). Do przewodniczenia obradom zaproszono ks. prof. dra hab. Anzelma Weissa oraz ks. prof. dra hab. Jana Szczepaniaka. Pierwszy referat pt. Schematyzmy (archi) diecezji przemyskiej jako źródło do badań nad dziejami Kościoła lokalnego i regionalnych badań społecznych w imieniu nieobecnego referenta ks. prof. dra hab. Stanisława Nabywańca (Uniwersytet Rzeszowski) przeczytał ks. mgr lic. Marcin Nabożny (Katolicki Uniwersytet Lubelski Jana Pawła II). Z referatu dowiedzieliśmy się, że pierwsze schematyzmy diecezji przemyskiej obrządku łacińskiego pojawiły się prawdopodobnie już pod koniec XVIII lub zaraz na początku XIX w. Początkowo 
ukazywały się sporadycznie, a ich periodyczność datuje się dopiero na okres dwudziestolecia międzywojennego. Niestety, I i II wojna światowa to całkowity brak możliwości ich wydawania, niewiele lepiej było również w okresie komunistycznym. Niektóre roczniki, co należy podkreślić, po dziś dzień pozostały wydane tylko w formie maszynopisu. Jednakże pomimo tych utrudnień stanowią one ważne, acz wymagające źródło, z którego chętnie korzystają tak historycy Kościoła, jak i historycy przeszłości społecznej i demograficznej.

Schematyzmy diecezji łódzkiej zaprezentował ks. dr hab. Mieczysław Różański prof. UWM (Uniwersytet Warmińsko-Mazurski). W swoim wystąpieniu podjął próbę ukazania procesu wydawania tego szczególnego wydawnictwa, które przedstawia strukturę organizacyjną diecezji i obsadę personalną poszczególnych urzędów, począwszy od centralnych urzędów diecezjalnych, a skończywszy na najmniejszych jednostkach - parafiach. Pierwszy tego typu katalog dla diecezji łódzkiej datowany jest na rok 1921 i wówczas przyjął on formę dodatku do kalendarza liturgicznego. W kolejnych latach zaczął występować jako corocznie wydawany samoistny periodyk, który w okresie przedwojennym nosił nazwę $S p i s d u$ chowieństwa i parafii Diecezji Łódzkiej, a następnie, w okresie powojennym: Diecezja Łódzka. Struktura terytorialno-administracyjna i duchowieństwo, Diecezja Łódzka. Terytorium Organizacja Duchowieństwo, i był wydawany co kilka lat. Obecnie obowiązuje nazwa zapoczątkowana w roku 1992 Archidiecezja Łódzka. Informator.

Z kolei ks. dr Tomasz Moskal (Katolicki Uniwersytet Lubelski Jana Pawła II) przedstawił Rubrycele i schematyzmy diecezji sandomierskiej (1818-1992), erygowanej przez papieża Piusa VII 30 czerwca 1818 roku na mocy bulli Ex imposita nobis. Jak podał referent, już w dwa lata później wydana została pierwsza rubrycela. Przez 174 lata, a więc do czasu reorganizacji diecezji na mocy bulli papieża Jana Pawła II z 25 marca 1992 roku, druki te publikowano pod różnymi tytułami: Elenchus, Directorium, Consignatio, Cathalogus. Dołączane do nich spisy parafii i duchowieństwa, od 1927 roku zaczęły wychodzić w postaci odrębnych wydawnictw, jako Rocznik Diecezji Sandomierskiej, Skrócony Rocznik Diecezji Sandomierskiej, Skrócony Katalog Diecezji Sandomierskiej, Spis parafii i duchowieństwa Diecezji Sandomierskiej. Wszystkie stanowią niezwykle cenne źródło do badań nad diecezją i szerzej - Kościołem, a komplet druków posiada Biblioteka Diecezjalna w Sandomierzu.

Zachowane natomiast w Archiwum Diecezjalnym w Drohiczynie rubrycele i schematyzmy stały się przedmiotem badań dra Marka Hałaburdy (Uniwersytet Papieski Jana Pawła II w Krakowie), który wystąpił z referatem zatytułowanym Rubrycele i schematyzmy diecezji pińskiej (1926-1939) zachowane w Archiwum Diecezjalnym w Drohiczynie. Badania nad tymi drukami, jak podkreślił referent, mają szczególne znaczenie, bowiem ze względu na zawieruchę dziejową, tj. wkroczenie wojsk sowieckich do Polski we wrześniu 1939 r. i zniszczenie, rozproszenie, bądź zaginięcie dokumentów wytworzonych przez kurię diecezjalną w Pińsku, stały się jednym z najważniejszych, a przy tym najłatwiej dostępnych źródeł do badania dziejów kresowej diecezji. Wydawnictwa te raz po raz zmienialy tytuły, które brzmiały: Kalendarium liturgicum dioecesis pinscenisi, Directorium di- 
vini offici et missarum pro dioecesis pinscensis, Ordo divini officii sacrique peragendi pro dioecesis pinscenis, Directorium divini officii et missarum ad usum dioecesis pinscensis, Directorium divini officii recitandi sacrique peragendi in dioecesis pinscensi, wespół z którymi, jako wydawnictwa samoistne, drukowano spisy kościołów i duchowieństwa. I właśnie Archiwum Diecezjalne w Drohiczynie, co wyraźnie podkreślił referent, posiada najbogatszą kolekcję tychże druków,

Ważną, mającą średniowieczne korzenie diecezję i wydawane przezeń rubrycele i schematyzmy przedstawił dr Piotr Kardyś (Polskie Towarzystwo Historyczne Oddział w Skarżysku-Kamiennej) w referacie zatytułowanym Rubrycele $i$ schematyzmy diecezji żmudzkiej z lat 1853-1914 zachowane w Archiwum Diecezjalnym w Kielcach. Archiwum Diecezjalne w Kielcach posiada kolekcję aż 30 druków, z których 27 rubrycel biskupstwa telszewskiego (według XIX-wiecznej nomenklatury Kościoła i administracji carskiej diecezję określano jako telsensi seu samogitiensi) z lat 1853-1909 ma w tytule directorium, a jedynie trzy $\mathrm{z}$ lat 1912-1914 ordo. W przypadku współoprawnych z nimi schematyzmów diecezjalnych, co podkreślił referent, zawsze używano nomenklatury elenchus i zgodnie z tradycją, obydwa druki współwydawano. W zbiorze znajdującym się w Archiwum Diecezjalnym w Kielcach brakuje druków za lata 1856-1859, 1863-1879, 1882-1883, 1885, 1894, 1896, 1899, 1903, 1908, 1910-1911, a więc w sumie za 31 lat. Jednakże, jak zasugerował dr P. Kardyś, w przypadku okresu powstania styczniowego i represji popowstaniowych nie było możliwości wydawania takich druków przez konsystorz, tym bardziej, że funkcjonowanie biskupstwa w okresie sedevacante (1875-1883) było mocno utrudnione. Mimo tych braków, co należy podkreślić, zbiór kielecki jest niezwykle pokaźny i może stanowić podstawę do analizy dziejów diecezji wschodnich.

Po krótkiej przerwie, wystąpieniem ks. dra Andrzeja Kwaśniewskiego (Archiwum Diecezjalne w Kielcach) pt. Rubrycele i elenchusy diecezji kielecko-krakowskiej oraz kieleckiej (1849-2014), wznowiono obrady Sesji II. Okres zasygnalizowany w tytule referatu był bardzo szczególny z punktu widzenia Kościoła kieleckiego, a to dzięki, początkowo, autonomii wikariatu apostolskiego, który w 1882 r. został wyniesiony do rangi diecezji. Z dziejami diecezji ściśle związana jest tradycja publikowania rubrycel i elenchusów uniezależnionych od władzy diecezjalnej w Krakowie. Od tego czasu, tj. od 1849 r., aż po dzień dzisiejszy wydawane są kieleckie rubrycele i elenchusy. Ks. dr A. Kwaśniewski podjął próbę opracowania tychże druków, pod względem bibliograficznym, rozważając jednocześnie ich przydatność do badań nad dziejami liturgii oraz badań historycznych. Zastrzegł jednak, że współczesne rubrycele wydawane od roku 1939 jako druki samoistne, będą stanowić przedmiot odrębnego opracowania i katalogu.

Kolejny referat na temat Ze zbiorów Archiwum Diecezjalnego w Kielcach. Rubrycele i schematyzmy diecezji tyraspolskiej 1858-1913 wygłosiła dr Sylwia Konarska-Zimnicka (Uniwersytet Jana Kochanowskiego w Kielcach). Autorka wystąpienia zaprezentowała analizę zgromadzonego w Archiwum Diecezjalnym w Kielcach materiału źródłowego, jakim jest 29 directoriów diecezji tyraspolskiej. Prezentując charakterystykę zachowanych rubrycel i schematyzmów umieś- 
ciła ją w szerokim kontekście historycznym, ważnym z punktu widzenia burzliwych, acz krótkotrwałych dziejów diecezji tyraspolskiej (ostatni z biskupów diecezji tyraspolskiej, bp Joseph Kessler, od 1919 r. zmuszony był do przebywania poza stolicą diecezji, a 27 listopada 1929 zrzekł się urzędu biskupa diecezji tyraspolskiej).

Dr hab. Maria Dębowska prof. KUL (Katolicki Uniwersytet Lubelski Jana Pawła II) omówiła Schematyzmy diecezji łuckiej i żytomierskiej (1801-1938). Już we wstępie referentka zasygnalizowała, iż schematyzmy diecezji łuckiej i żytomierskiej z lat 1801-1939 łączą w sobie informacje o duchowieństwie i strukturach kościelnych trzech organizmów diecezjalnych - diecezji łuckiej (1801-1938), żytomierskiej (1801-1925) i kamienieckiej (1866-1918), których dzieje w niezwykle widoczny sposób oddziaływały na treść rubryceli i schematyzmów. Rubrycele bowiem wydawano przez wiele lat jako odrębne druki dla każdej diecezji - łuckiej i żytomierskiej. W roku 1865 po raz pierwszy opracowano wspólny kalendarz liturgiczny dla diecezji łuckiej i żytomierskiej z przeznaczeniem na rok 1866. Dr hab. M. Dębowska zwróciła uwagę, iż do rubrycel dołączono jeden, wspólny dla obydwu diecezji spis duchowieństwa i parafii. Dwa lata później, w druku na 1868 r., do spisu duchowieństwa i parafii diecezji łuckiej i żytomierskiej dołączono wykaz duchowieństwa i parafii w diecezji kamienieckiej. Autorka wystąpienia niezwykle precyzyjnie scharakteryzowała w/w druki, nieustannie podkreślając rolę rubrycel i schematyzmów w zgłębianiu wiedzy na temat ciągle zbyt mało znanych diecezji wschodnich.

Rubrycele i schematyzmy diecezji rzeszowskiej (1992-2014) zaprezentował ks. mgr lic. Marcin Nabożny (Katolicki Uniwersytet Lubelski Jana Pawła II). Diecezja rzeszowska została utworzona w roku 1992 (wydzielono ją z diecezji przemyskiej - 14 dekanatów i tarnowskiej - 5 dekanatów), zatem jej schematyzmy należą do najnowszych tego typu źródeł. Pierwszy, zawierający wykaz parafii i podstawowe dane adresowe schematyzm wydano w 1992 roku. W 1993 roku ukazał się pełniejszy druk, który zawierał informacje dotyczące parafii, kapłanów, duszpasterstw specjalistycznych, zakonów, zgromadzeń pełniących posługę w diecezji oraz najbardziej potrzebne dane dotyczące Kościoła w Polsce i na świecie; z czasem zaczęto dołączać do schematyzmów mapy diecezji (1993, 1995-1997, 2000-2003, 2010, 2012, 2013) oraz mapy dekanatów $(1993,2000$, 2010). W latach: 1994, 1999, 2008 i 2009 nie opublikowano schematyzmów diecezjalnych. Natomiast w latach 2000 i 2010 opublikowano znacznie poszerzone schematyzmy jubileuszowe, będące znakomitym świadectwem prężnej działalności diecezji.

Ostatnim wystąpieniem Sesji II był referat ks. dra Sławomira Zycha (Katolicki Uniwersytet Lubelski Jana Pawła II) pt. Katalogi Duszpasterstwa Polonijnego we Francji. Jego powstanie związane jest z działalnością założonej w 1922 r. Polskiej Misji Katolickiej we Francj. W 1939 r. opublikowano pierwszy schematyzm Duszpasterstwo Polskie we Francji, który liczył zaledwie cztery strony druku i odzwierciedlał stan misji z 15 I 1939 r. Kolejny katalog ukazał się w 1940 r. (stan z 1 III), a po kapitulacji Francji w 1940 r., zawieszono ich wydawanie. Druk schematyzmów wznowiono po zakończeniu działań wojennych, w 1946 r. Zmie- 
niono wówczas szatę graficzną druków i wzbogacono ich treść, na skutek czego kolejne edycje schematyzmów coraz bardziej upodabniały się do schematyzmów diecezjalnych, czego przykładem jest Informator Polskiej Misji Katolickiej opublikowany w Paryżu w roku 1995.

Sesję II zakończyła ożywiona dyskusja, w którą włączyli się nie tylko referenci, ale również licznie przybyli na konferencję przedstawiciele kieleckiego środowiska akademickiego oraz członkowie i sympatycy TPADK.

Przerwę pomiędzy sesjami wypełniło zwiedzanie Wyższego Seminarium Duchownego w Kielcach, po którym uczestników konferencji oprowadzali członkowie Koła Historycznego Wyższego Seminarium Duchownego w Kielcach.

Sesję III konferencji poświęcono Schematyzmom zakonnym. Jej przewodniczący, br. dr hab. Michał Gronowski OSB (Opactwo w Tyńcu, Uniwersytet Śląski) jako pierwszy wygłosił referat pt. Elenchusy benedyktynów polskich. Już na wstępie referent zasygnalizował złożoność podjętego problemu. Jak podkreślił, elenchusy związane są ze strukturą organizacyjną instytucji, do której się odnoszą, a przecież benedyktyni nie tworzyli scentralizowanego zakonu. Nie wiadomo, jak podkreślił dr hab. M. Gronowski OSB, czy przed XVIII wiekiem dokonywano spisów w poszczególnych opactwach. Dopiero w XVIII w. wraz z utworzeniem polskiej kongregacji łączącej wszystkie benedyktyńskie klasztory (1709 r.) miały odbywać się kapituły generalne, po których zarząd kongregacji był zobowiązany do wydania drukowanego katalogu podającego spis mnichów danych opactw wraz z datą urodzenia, profesji, święceń, dołączając wykaz zmarłych. Po dziś dzień zachowały się druki z lat: 1759, 1768, 1774, 1780, 1800, 1777, 1780, 1783, 1787, 1792, 1797 i 1819. Wydawano je pod różnymi tytułami: Catalogus monasteriorum, Catalogus personarum, Nomina virorum et defunctorum professorum, Series abbatum praelatorum et monachorum. Natomiast dyspozycje liturgiczne dla poszczególnych opactw wydawano w odrębnych rubrycelach. Referent, analizując zachowany materiał źródłowy, podkreślił konieczność przeprowadzenia dalszych, pogłębionych badań nad tymi szczególnymi informatorami.

Kolejny referent, o. dr Sławomir Brzozecki OP (Katolicki Uniwersytet Lubelski Jana Pawła II) przedstawił referat zatytułowany Schematyzmy diecezji litewskiej (od 1839 litewsko-ruskiej) prowincji dominikanów. We wstępie omówił losy litewskiej prowincji dominikanów, która, w wyniku rozbiorów Rzeczypospolitej, prawie $\mathrm{W}$ całości znalazła się pod panowaniem rosyjskim. W prowincji tej pod koniec XVIII w. zaczęto wydawać rubrycele, a od ok. 1817 r. osobno drukowane schematyzmy. Niestety, na skutek kasaty zakonów w 1832 r. w Imperium Rosyjskim doszło do połączenia się w roku 1839 litewskiej i ruskiej prowincji dominikańskiej w jedną litewsko-ruską, a wkrótce do jej całkowitej likwidacji. Ponadto, zawiłe losy prowincji utrudniają sporządzenie wykazu schematyzmów dominikanów litewskich, które można spotkać w bibliotekach i archiwach w Polsce, na Białorusi, Litwie, Łotwie, Ukrainie oraz w Rosji. W oparciu o druki, do których udało się autorowi wystąpienia dotrzeć, można zarysować skład personalny i organizacyjny prowincji, klasztorów, szkół publicznych, a także placówek duszpasterskich w Rosji. Niestety, obraz ten nadal jest fragmentaryczny i można tylko żywić nadzieję, że uda się dotrzeć do jak największej liczby zachowanych schematyzmów diecezji litewskiej i litewsko-ruskiej. 
Katalogi zakonne nazaretanek w zbiorach Archiwum Prowincji Krakowskiej Zgromadzenia Sióstr Najśw. Rodziny z Nazaretu to tytuł wystąpienia s. mgr lic. Danuty Kozieł CSFN (Archiwum Nazaretanek Prowincji Krakowskiej w Krakowie). Najstarszy katalog zakonny nazaretanek pt. Wykaz domów Zgromadzenia Sióstr Najśw. Rodziny z Nazaretu został wydany w języku polskim w Rzymie w 1961 roku (choć druku dokonano w USA). W zbiorach biblioteki podręcznej w Archiwum Prowincji Krakowskiej znajduje się 25 drukowanych katalogów zakonnych z lat 1971-2013, co stanowi większość z wydanych ksiąg. Katalogi z lat 1966-1989 były w całości publikowane w języku angielskim. Od 1990 roku spisy, dla których przyjęto nazwę Directory, sporządzano w języku kraju, w którym znajduje się określona prowincja. Druki z lat 1961-1989 zawierały jedynie spisy domów według prowincji, daty ich założenia, dane adresowe, informacje o diecezjach, w których istniały. Od 1990 roku dołączono spis sióstr, z uwzględnieniem ich danych osobowych. Zamieszczono tu również wykaz instytucji i dzieł prowadzonych przez nazaretanki w poszczególnych prowincjach. Cytując referentkę „Katalogi wydawane w Zgromadzeniu Sióstr Najśw. Rodziny z Nazaretu dla historyka zajmującego się dziejami Kościoła stanowią źródło do wstępnego zapoznania się z działalnością i funkcjonowaniem nazaretanek w okresie minionych 40 lat. Są także niezastąpione w poszukiwaniach podstawowych informacji o siostrach i ich cirriculum vitae zarówno dla potrzeb opracowań historycznych, jak i dla bieżącej działalności kancelaryjnej.

Ostatni referat Sesji III i jednocześnie konferencji wygłosiła mgr Edyta Chomentowska (Katolicki Uniwersytet Lubelski Jana Pawła II). Przedmiotem analizy uczyniła Schematyzmy karmelitów trzewiczkowych. Swoje wystąpienie rozpoczęła od podkreślenia faktu, iż karmelici trzewiczkowi to jedyny w Polsce zakon z pięcioma prowincjami zakonnymi. Do 1772 r. liczył ponad 900 zakonników skupionych w 59 domach. Niestety, rozbiory Polski bardzo niekorzystnie wpłynęły na losy zakonu - do 1918 roku przetrwało jedynie sześć domów w prowincji galicyjskiej. Już w połowie XIX w. zaczęto wydawać schematyzmy, które miały bogatą ikonografię, stały układ treści, na którą składały się informacje dotyczące składu osobowego poszczególnych domów, wykaz zmarłych, czasami poczet przełożonych, ponadto dane o poszczególnych kościołach. Treść zachowanych katalogów pozwala zatem rozpoznać liczebność wspólnoty i rotację zakonników w poszczególnych klasztorach. Jak podkreśliła mgr Edyta Chomentowska, a co stało się swoistą myślą przewodnią konferencji, schematyzmy kształtowały samoświadomość zakonników, stąd nie do przecenienia ich rola w odkrywaniu przeszłości.

Po wysłuchaniu ostatniego wystąpienia Przewodniczący Sesji III otworzył dyskusję. Aktywnie włączyli się w nią nie tylko czynni uczestnicy konferencji, ale również licznie przybyli przedstawiciele miejscowego środowiska akademickiego, jak również zainteresowani problematyką sympatycy TPADK. Następnie dr P. Kardyś, wiceprezes TPDAK dokonał podsumowania obrad. Dziękując wszystkim referentom za ciekawe wystąpienia i towarzyszącą im dyskusję, szczególne podziękowania skierował w stronę inicjatora i głównego organizatora konferencji, ks. dra A. Kwaśniewskiego. Podkreślił znaczenie tego typu spotkań nauko- 
wych dla rozwoju badań nad niezwykle bogatymi zasobami archiwów kościelnych w Polsce i poza jej granicami. Wyraził również nadzieję, że badania te będą kontynuowane. Następnie uczestnicy konferencji zostali zaproszeni do zwiedzenia Archiwum Diecezjalnego w Kielcach, po którym oprowadził ich ks. dr Andrzej Kwaśniewski, dyrektor archiwum. Z jego inicjatywy uczestnicy konferencji mogli również zwiedzić kościół i klasztor sióstr bernardynek na Świętej Katarzynie, dzieje których przybliżali członkowie Koła Historycznego Wyższego Seminarium Duchownego w Kielcach.

Na ostatni dzień konferencji - 25 maja 2014 r. - zaplanowano objazd naukowy i zwiedzanie kościoła i zamku biskupów krakowskich w Bodzentynie oraz kościoła w Tarczku. Bogatą historię tych jakże ważnych dla regionu miejsc przedstawił dr Piotr Kardyś. Uczestnicy konferencji mogli również zwiedzić Archiwum Państwowe w Kielcach, po którym oprowadziła ich dyrektor Wiesława Rutkowska; ponadto Muzeum Narodowe w Kielcach i kielecką katedrę. Ten wyjątkowo bogaty objazd naukowy zwieńczył konferencję, której celem było nie tylko uświetnienie obchodów jubileuszu 75-lecia Archiwum Diecezjalnego w Kielcach i próba zainteresowania badaczy rubrycelami i schematyzmami, ale także ukazanie piękna regionu świętokrzyskiego, mogącego się pochwalić wspaniałą historią, a dzięki temu dysponującego potężnym potencjałem kulturowym. 